\title{
The Impact of Work-Life Quality on Staff Performance at Dawadami Public Hospital, Saudi Arabia
}

\author{
Rashed Ghazi Al-Howil Al-Otaibi \\ Department of Business Administration, College of Sciences and Humanities, Shaqra University, Shaqra, Saudi Arabia \\ Email: ralotaibi@su.edu.sa
}

How to cite this paper: Al-Howil Al-Otaibi, R. G. (2020). The Impact of Work-Life Quality on Staff Performance at Dawadami Public Hospital, Saudi Arabia. Journal of $\mathrm{Hu}$ man Resource and Sustainability Studies, 8, 107-130.

https://doi.org/10.4236/jhrss.2020.82007

Received: April 21, 2020

Accepted: May 18, 2020

Published: May 21, 2020

Copyright $\odot 2020$ by author(s) and Scientific Research Publishing Inc. This work is licensed under the Creative Commons Attribution International License (CC BY 4.0).

http://creativecommons.org/licenses/by/4.0/

\begin{abstract}
This study investigates the impact of the quality of working life in its various dimensions on the performance of employees at Dawadami General Hospital. The model was evaluated based on the respondents' responses by assessing the apparent validity of the survey, the validity of the convergence, the internal consistency, the consistency of the structure, and the recognition's validity, in order to ensure that the survey statements were appropriate to the model before performing structural analysis and hypothesis tests. To analyse data and test hypotheses, we used various statistical methods. The empirical results showed a strong correlation between the dimensions of the quality of working life (salaries and wages, occupational health and security, job satisfaction, opportunities for advancement and career progression, dominant leadership style, and work environment) and the performance of the staff at Dawadami Hospital. It also showed a moral impact by the dimensions of the quality of working life on the level of the job performance of the staff. Moreover, the results indicated no significant differences in opinion about all its dimensions among the study sample, whether by type, age, educational level, job type, number of years of service, or salary.
\end{abstract}

\section{Keywords}

Quality of Work Life, Staff Performance, Public Hospitals

\section{Introduction}

The success of any organisation depends to a large extent on the people it employs and the degree of their loyalty, as the prevailing competitive work environment and technological changes affect both job opportunities and the need to retain competent employees, quite apart from management strategies, policies 
and approaches to human resource management. Levering (1988) confirmed that the success of organisations and the achievement of goals cannot happen at the expense of employees, and that the most important way to create a distinct workplace is for organisations to focus on constantly improving the quality of life at work within their social and technical environments to ensure compatibility and success. Lawler \& Nadler (1983) report that quality of working life refers to "an individual's perception and attitudes towards his work and the overall work environment"; in simple terms, the quality of working life can be defined as an individual's satisfaction with his work and with the overall work environment in the organisation.

The quality of life at work encourages industrial democracy and, therefore, for the organisation's survival and prosperity, management must strive to create a quality of life that contributes to the organisation's success in achieving its goals. Undeniably, the increased job satisfaction of employees brought by a higher quality of career life will be a factor in this success: the well-being of the organisation as a whole, job satisfaction in general and achieving a high quality of life at work enable the organisation to thrive and improve, and increase the effectiveness of operations and efficiency, so there is a clear need for management to revisit the improvement of working life standards from time to time. On the other hand, the aspirations of employees have changed radically, following Maslow's hierarchy of needs, in accordance with the job opportunities available to them, and they are willing to move jobs to fulfil their aspirations. This poses a challenge for senior management, increasing the difficulties of maintaining a business in a competitive environment, and requiring organisations to analyse their business environment and strive to improve the quality of life at work for its employees. Hence, quality of career life has become an important element in the era of global competitiveness in attracting and retaining competent employees, and it is imperative for business organisations to maintain a high level of quality of life at work, to meet staff aspirations, as confirmed by a review of the literature and applied studies conducted in this field in different business environments, during different time periods and on different administrative activities and levels.

In common with other organisations, public hospitals depend on the efficient use of human resources to achieve high-quality outputs. As effective organisations, they are concerned with those matters affecting their workers which increase the level of their job satisfaction, raise their morale and improve their level of performance. In the light of rapid changes in the local business environment, pressures associated with increasing competition, and transparency among service providers in the health sector, organisations ensured they developed policies and strategies to build trust with their workers, motivating and reassuring them, to enable a high level of performance: providing a career structure and a safe and healthy work environment motivates quality performance and raises the hospital's competitiveness.

Reviewing the literature on the various dimensions of career quality and the 
proven importance of quality of the work environment in developing performance, we have developed a set of issues which indicate insufficient clarity around the quality of life at work and the extent to which this can be applied at the Dawadami public hospital. In addition, in reviewing the previous relevant studies, a research gap was found in the area of the quality of the working environment and workers' performance in the health sector in the Kingdom, giving an opportunity to study dimensions of the quality of the working environment at Dawadami public hospital, and to improve the level of performance of its employees.

The main objective of this study is, therefore, to examine the factors associated with the quality of the working environment that affect the performance of workers at the Dawadami public hospital. Specifically, this study contributes to the literature by examining the following questions: Firstly, is there a relationship between the quality of life at work and the performance of workers at Dawadami Hospital? Secondly, does the quality of working life impact on the level of workers' performance? Thirdly, is there a variation in the level of employees' awareness of the quality of life at work and its impact on performance according to personal factors?

This article is organized as follows. The next section presents the research importance. Section 3 describes the hypotheses and variables used. Section 4 reviews the previous literature on the relationship between the working-life quality and staff performance. Section 5 describes the theoretical framework. Section 6 presents the methodology. Section 7 discusses the empirical results. Section 8 concludes and gives some recommendations.

\section{Research Importance}

\subsection{Theoretical Level}

The concept of quality in working life is considered one of the most important concepts currently, especially if it is used effectively in public health institutions and the current study, therefore, is in line with the desired administrative development and represents a response to many recommended Arab and foreign studies that are recommended, particularly in light of the lack of comparable Arab and Saudi studies and, especially, applied studies in the health sector.

This study contributes to the cognitive accumulation in this field, confirming the nature of the relationship between quality of work environment and performance by applying it to a distinct work environment, both geographically, i.e. the Saudi work environment, and in the field of application, i.e. the work environment in health services, which is naturally distinct from other services.

The definition of the components of the quality of life at work, as applied to a specific work environment, will help researchers, academics and human resource executives to develop and implement these components.

\subsection{Practical Level}

The importance of this study derives from its identification of the most important elements affecting the quality of life at work and the efficiency of hospital 
staff performance at Dawadami hospital, as related to a number of personal and functional variables, including age, nationality, educational qualifications, number of years of experience, social status, recognition of job satisfaction and the relationship that binds the employee with superiors and colleagues. The study will attract the attention of managers, supervisors and operators in the process of improving performance and human resources management. It is hoped that, due to concern for the performance of employees whom they directly supervise, they will afterwards develop programmes to improve performance through an interest in the organisation's quality of life at work.

The results of this study may provide advice and guidance to decision-makers in the health sector, who are able then to take necessary actions to enhance dimensions of career quality. The study will identify the working environment factors which most affect the workers' performance at Dawadami hospital, contributing to an improvement in the performance of workers and raisings their level of productivity. Benefit from the results of the applied study and determining the basic dimensions of career life quality, in order to achieve a higher level of performance and an improvement in the level of provided health services.

\section{Hypotheses and Variables}

\subsection{Hypotheses}

The hypotheses were developed to measure the correlation of the quality of working-life in its various dimensions as independent variables, with the job employees' performance as a dependent variable, which are:

H1: There is no significant relationship between the dimensions of working life quality and staff performance.

$\mathrm{H} 2$ : Working life quality has no significant effect on the performance levels of employees.

H3: There are no statistically significant differences between the averages of the respondents' responses in regard to their views on the quality of working life as its impact on the job performance of employees is due to personal and functional variables.

\subsection{Variables}

Independent or Interpreted Variables

Researchers focus on studying the quality of working life in its various dimensions, in order to improve its quality, to achieve better performance, to stimulate the creativity of individuals, to enhance competitiveness and to create a culture of creativity and development. The health services, particularly in the Kingdom of Saudi Arabia, include workers with a variety of cultures, which vary with increased numbers of expatriates working in hospitals, as their motives are varied. It is, therefore, necessary to define the most important dimensions of working life quality, which affect the quality of the hospital's career in a way that helps decision-makers and officials in setting policies, developing programmes and 
making decisions that help achieve a high level of working life quality, and then improve the service and achieve the best possible performance. Ways of providing working life quality have evolved over time. During the 1970s, Walton (1974) used a number of elements, the most important of which are providing adequate and fair compensation; providing safe and healthy working conditions, achieving opportunities for continuing growth and security; providing more space for social life and achieving social integration at work; and complying with administrative laws in business organisations. It has been widely believed that employees work for financial reward only and, accordingly, studies have adopted a measure of the quality of working life for workers based on this hypothesis. However, actual practice, literary works and applied studies have indicated that these motives have fundamentally changed, and that quality of working life has many aspects. This study, therefore, represents an attempt to identify the most important components of quality of working life, those with most influence in the Saudi work environment and, particularly, in the field of health services, so that senior management can work to develop the quality of working life and raise the hospital personnel's level of performance.

The list of determinants and review of the literature are not comprehensive in including all theories and variables, as it is intended to focus the study on the most frequently occurring elements in the literature, while aligning them with the Saudi work environment and the practical field conditions in healthcare services (Mackintosh \& Langley, 2007). Therefore, in light of the survey, a number of sub-determinants were chosen which are listed below:

- The Main Variable: the quality of working life, with a number of sub-variables of different dimensions derived from it, as follows:

Dimensions Related To Organisational and Functional Aspects

- Leadership and supervisory behaviour

- Job satisfaction

Dimensions Related to the Physical and Moral Work Environment and Conditions:

- Security and occupational health

- Work environment

Dimensions Related To Financial and Economic Aspects

- Wages and bonuses

- Opportunities for promotion and career advancement

* Dependent Variable: The Functional Performance of Hospital Staff

The main dependent variable is the level of job performance of workers at the Dawadami public hospital which, in turn, determines the organisation's performance. Job performance is defined as achievement of the primary objectives of the job role, and is the final outcome of all existing activities that use all available resources in order to achieve the objectives effectively and efficiently. Good performance is a combination of efficiency in the use of available resources, together with a high degree of achievement and effectiveness, based on the worker's execution of the main tasks entrusted to them in their job, whether that be as a 
doctor, nurse, technician or administrator. In other words, functional performance is an employee's accomplishment of their work duties and responsibilities, using the available organisational resources, in addition to the outcome of those achieved actions or results. Therefore, the process of measuring functional performance is based on employee perceptions regarding a set of standard dimensions, reflecting the extent of commitment to systems, availability of materials, level of achievement, efficiency in using available resources and extent of achievement of objectives or, in summary, achieving a high degree of accomplishment, i.e. effectiveness, with well-utilised resources, i.e. efficiency.

The determinants of functional performance are the following:

Self-efficacy, adherence to instructions and work regulations, work turnover (willingness to quit work), reward and punishment systems, complaint cases and grievances, adherence to objective standards, dealing with emergencies, satisfaction regarding the dimensions of working life quality and work productivity.

\section{Previous Studies}

Hamzah et al. (2014) focused on the impact of leadership methods on the yields of government facilities in the Kingdom of Saudi Arabia based on data of $400 \mathrm{em}$ ployees working in sixteen government ministries. Equation modelling (PLS-SEM) was used to test the study hypotheses. One of the most important results of this study is the demonstration of a major impact from the leadership methods on the job yield, which indicates that the improvement of organisational performance in Saudi public services is the result of effective and responsible leadership. Al-Thunaian (2013) measured the performance in government facilities, applying the Balanced Scorecard Concept (BSC) method. This method gives limited attention, especially in health care facilities. To measure the performance of government organisations, the study made a distinction between financial and non-financial dimensions and a framework was developed that reflects the main factors when applying the BSC in measuring the performance of government health facilities. This study was applied at the King Faisal Specialised Hospital and its Research Centre, and included five main areas: medical care, employees, quality of care, education and research and financial matters, but employees found it difficult to understand the balanced scorecard method. Sinha (2012) examined QWL in organisations, surveying 100 employees in middle management positions in different facilities, and found three different elements within the institutions: "the orientation towards relationship support", "occupational future and "career and self-direction and systems". The results indicated the important role that these factors play in satisfying the needs of workers to develop excellence in their working life within a social framework.

Bakar et al. (2015) focussed on the role of organisational support in QWL in the insurance industry in Malaysia. The study was applied to 450 workers in the private sector and found that a general economic improvement impacted positively on QWL leading to increased employee satisfaction. There is a strong rela- 
tionship in health fields between welfare and work pressure on one hand and QWL on the other hand, where the better these dimensions are, the higher the productivity and the extent of staff satisfaction. Saleem \& Khurshid (2014) focussed on answering the following question: "Do human resource practices affect the job performance of workers?" The study also examined the relationship between such practices and job performance of workers, using a sample of 500 employees in 29 branches of the three largest Pakistani banks in Lahore. The results showed a strong association between compensation provided on the basis of excellence, transparency in selection and appointment, training, development programmes and organisational commitment on one hand, and improved job performance by workers on the other hand.

Kazan \& Gumus (2013) examined the most important factors affecting the performance of workers in a Turkish bank with a survey of 20,000 employees. A sample of 500 employees was identified, and the survey list was used as a study tool. The results are significant in that they find no positive impact on the performance of employees from the following factors: level of job satisfaction, salaries or promotion systems. Elhosni (2016) examined the effect of QWL in enhancing organisational commitment among social researchers in the Ministry of Social Affairs in Gaza. An analytical descriptive approach and a comprehensive survey method were used. Among the most important results, this study found that QWL affects organisational commitment positively. This study also recommended enhancing the QWL within the ministry by finding a systematic way to pay salaries, create a safe space for stability, and enable increased confidence in social researchers to make decisions. Essouiti (2016) explored the impact of QWL on organisational loyalty among workers within Palestinian government ministries, using the descriptive analytical approach and found a failure to respect staff within government ministries, an absence of justice, weak organisational integration, low wages and a lack of motivation among the employees. The study also recommended maintaining high morale among employees within government ministries, setting policies and strategies that align with the objectives of the employees, and holding workshops on working life programmes within Palestinian government ministries. Mahmoud (2015) investigated the relationship between QWL and managerial creativity in promotional activity officials in Egyptian universities. The study also identified expected perceptions of QWL in light of administrative creativity, and found that there is a relationship between managerial creativity and the quality of work life. Elomri \& Randa (2017) examined the impact of elements of QWL on the performance of civil servants, and also examined the measurement of the difference between personal factors and performance, the relationship between the employee and employer, material and moral incentives and work environment. The analytical descriptive approach was adopted using a questionnaire distributed to 2500 civil servants in the Kingdom of Saudi Arabia, and found an effect of elements of QWL on job performance. Among these elements were the employee's relationship with colleagues and manager, job satisfaction and material incentives. The study con- 
cluded that there were statistically significant differences in job performance and career satisfaction, employee relationships with manager and colleagues and many other variables.

\section{Theoretical Framework}

Quality of Working Life (QWL)

The term QWL dates back to the International Labor Relations Conference that took place in 2791, in Arden House at Columbia University, New York (Davis \& Cherns, 1975). Although there was no agreement on the definition of quality of working life, it was widely recognised as being related to the quality of workers life and welfare. After its use by Mills (1978), it became one of the basic concepts in business management organisations, both in practice and in the literature. QWL has become an important determinant since it was found that the work environment is related to the satisfaction of employees and their behaviour in work (Greenhaus, Collins, \& Shaw, 2003), and influences employee reactions and personal alienation, improves performance, and affects employees loyalty to the organisation and work turnover rate (Carter et al., 1989; Efraty \& Sirgy, 1990). The concept began to spread widely when both GM and the Auto Workers Union introduced QWL programmes within their career reform plans (Efraty et al., 1991). Some studies confirm that QWL differs from job satisfaction (Quinn \& Shephard, 1974; Staines, 1980; Champoux, 1981; Lawler, 1982) but leads to it, as QWL indicates the impact of the workplace on functional satisfaction and working life, as well as the satisfaction of workers about aspects of their life away from work and satisfaction with life in general (Sirgy et al., 2001). The study by Mrema \& Battu Nagaraju (2016) indicates a strong correlation between QWL, job satisfaction and organisational performance; the study confirmed that the quality of human input is the greatest asset to any organisation, and that the quality of this human input increases when higher levels of QWL are achieved.

- The Concept of QWL

Although the concept of QWL was developed over three decades ago, interest in the structure and its components continues. During the 1990s, there was renewed interest from researchers and practitioners in studying the concept, and it became more important to organisations in the development of their human resources, both in terms of job satisfaction of employees and the overall performance of the organisation.

Definitions of the concept of QWL have multiplied due to the diversity of the concept's dimensions, although the content remains the same: to improve the work environment, raise the morale of workers, provide the best services and improve performance. Some of these concepts are presented below according to the literature. Some defined QWL as employee expectations towards business organisations in terms of fairness, wages, compensation, a safe and healthy environment, human capacity development, and an amount of stability (Walton, 1974). Werther \& Davis (2002) emphasised the elements of job security and the balance between personal life and work, while others argue that QWL means 
providing adequate work conditions, good supervision, highly rate dmaterialistic and moral salary and bonuses, as well as the organisation providing some interest in the job (Werther \& Davis, 2002). Daud (2010) defined QWL as the appropriate work conditions and environment for employees in a range of aspects, which include maturing, career development, participation in decision-making, and a healthy physical environment. It has been claimed that QWL is considered by employees to be one of the organisation's assets, rather than being considered costly to it. Employees perform better when they are allowed to manage their own work, contribute to decision-making and take responsibility; this orientation motivates employees, meeting their physiological as well as their economic needs (Kamalraj \& Indumathy, 2012).

- Elements of QWL

Some researchers argue that QWL is a combination or a construct of concepts, which includes dimensions outside the scope of work such as contentment in life (situated at the top of construct), job satisfaction (in the middle of construct), and many other dimensions of job satisfaction, including payment, work collaboration and supervision, which lie at the bottom (Cherns \& Davis, 1975). A QWL literature review refers to a wide range of components and their measurements, including work environment, job satisfaction, opportunities for promotion and progress, appropriate and fair compensation, emotional intelligence, organisational commitment, organisational culture, joint relationship and work, job security, career fatigue, leadership styles, nature of work, facilities, job independence, employee position, job challenges and responsibilities, training and development and adequacy of resources. The most important dimensions of QWL, to be examined in this study, can be limited to the following: salaries and wages, opportunities for advancement and progress, work environment, job security and occupational health, job satisfaction, and leadership styles.

- Salaries and Wages Adequate and Fair Compensation

A wage is defined as the basic salary paid to an employee in exchange for his efforts in the workplace, considered the main source of income upon which the employee depends to satisfy his essential needs. It is also considered one of the most important motivational factors encouraging employees to work hard to achieve organisational goals: workers' satisfaction depends to a large extent on earning fair wages and bonuses. Organisations usually determine salaries and bonuses according to academic qualifications, work experience and the employee's personal skills. Wages are one of the most important factors in QWL, because they represent the extent to which an individual can satisfy his needs and requirements. A system of fair wages and bonuses makes workers believe they are in the right organisation and they see their job as their economic source. Many studies have demonstrated that salary is one of the components to measure the quality of workers' lives, as the results of the studies showed that there is a positive and significant correlation between adequate compensation, fair bonus systems, and QWL (Chanana \& Gupta, 2016; Nanjundeswaraswamy \& Swamy 2015; Swamy, 2013). 
- Opportunities for Promotion and Advancement

Promotion is defined as the reallocation of an individual to a higher level, and to a job that contains duties, responsibilities and powers greater than the current one. Opportunities for promotion are one of the most important factors that motivate workers to improve their performance, develop their capabilities and achieve functional stability (Abu-Sheikha, 2010). They are thus job satisfaction factors, which have a significant impact on employee performance and morale, and create a strong incentive to increase progress and growth and improving productivity, the impact of which is reflected in enhancing the organisation's performance and achieving its purposes. Promotion opportunities are considered to be one of the main components in rating QWL (Rani, 2016; Jagatheesh, 2013; Stein, 1983; Orpen, 1981; Walton, 1973).

\section{- Work Environment}

The work environment is defined as the place where the individual works, and also refers to the social and professional environment in which the individual interacts with other people, coordinating and cooperating with them to achieve the goals of the organisation. The work environment also includes occupational safety conditions, encompassing the services and equipment that provide protection for the individual. A worker with good health records high productivity, which means healthy employees are invaluable to the organisation. The work environment includes various safe, physical and mental working conditions, reasonable working hours, working conditions and time for personal care, support in self-development and work-related information. The organisation should strive to create a healthy and safe work environment to enable employees to work with confidence and without fear of harm, damage or diseases, as well as seeking to reduce medical risks and physical injuries. Studies by Rani (2016), and Karimi, Daraei, \& Farajzadeh (2015) confirmed a positive correlation relationship between QWL and work environment, for some time, researchers have focussed on the work environment as a major factor in measuring employees' quality of working life (Karimi, Daraei, \& Farajzadeh, 2015).

- Stability and Job Security

Occupational stability and security are vital for workers in all organisations, and form one of the most important pillars of success in any organisation because they create an atmosphere of reassurance and affiliation, which drives workers to be creative and make effective decisions in order to achieve the strategic goals of the organisation. Yousef (1997) indicates that job security reflects the employee's length of service in the same organisation without a wage decrease, maintaining insurance and pension rights, which have a positive impact on productivity, increasing employee job satisfaction and their commitment to achieving goals of the organisation. Job security is important to staff, and permanent work provides staff with security and improves their quality of work life, as confirmed by the studies of Karimi, Daraei, \& Farajzadeh (2015), Jagatheesh (2013) and Stephen \& Dhanpal (2012), suggesting that job security has a positive and moral connection with QWL. The literature contains a growing number of studies 
showing that job security is an important factor in determining QWL for workers (Rezaeean, Bolhari, Bairamzadeh, \& Soltan, 2011).

- Job Satisfaction

Satisfaction is generally defined as a feeling of happiness or joy experienced as a result of satisfying a need or desire. Job satisfaction means the way employees look at their work, and includes comfort at work, job security and stability, productivity, union activity, fair salary, leadership and job empowerment. Studies by Khera (2015) and Maghaminejad \& Adib-Hajbaghery (2016) examined the importance of job satisfaction as an essential component in the QWL and many researchers have found job satisfaction to be an important component in an employee's QWL case measurement (Manhas, 2013).

- Leadership Style in the Organisation, Leadership Styles

Leadership is defined as the process of interaction between the head and subordinates, in which the head is able to positively influence their behaviours and feelings and motivate them to work towards achieving the goals of the organisation. Leadership is also known as the social impact process, as the leader seeks to influence the subordinates and urge them to participate voluntarily in achieving the goals of the organisation. With rapidly globalised variables, organisations need effective leaders for these variables, who are able to attract and motivate workers to achieve the organisation's goals. There are three behavioural patterns for a leader according to the validity of use: Democratic Leader, Authoritarian Leader and Messy Leader. Studies by Pratama (2015) and Rubel \& Kee (2014) concluded that leadership styles have a significant effect on QWL for workers. From the above, we can conclude that the QWL is an umbrella term that includes many administrative initiatives, such as salary and wages systems, opportunities for promotion and career advancement, work environment security and safety, leadership and supervisory style, and increased job satisfaction for workers. It was also noted that each researcher used dimensions of QWL appropriate to the circumstances and the nature of the work environment. In the light of previous studies, this study will use a survey, and focus on the Saudi work environment and the nature of the health care sector. Salaries and wages, and opportunities for promotion and career advancement, are related in the financial and economic aspects of QWL; work environment, job security and occupational health fall within the physical and moral work environment, while job satisfaction and leadership style represent the functional and organisational aspects of the QWL components.

* Evaluating the Performance of Workers

The performance evaluation process, taking place at all job levels from senior management to workers, is an essential tool ineffective administration, whereby actual performance is compared to targeted performance. It is a means of urging departments to work with vitality and spirit through continuous monitoring of workers' performance by their superiors; it drives subordinates to work actively and efficiently to appear productive in front of their superiors, and to be eva- 
luated at a level qualifying for incentives and allowances. For the process to achieve its intended objectives, it must be handled in a systematic and accurate manner, with the participation of all parties who benefit from the final results (Hartmann \& Splanicar, 2009). Nyaoga et al. (2010) have pointed out the importance of performance evaluation in identifying competencies and seeking to raise capabilities; it can be an indicator of organisational climate, motivation level and employee satisfaction. Allagui (2007) defined performance evaluation as the process of measuring an employee's adherence to the behaviours required to complete the work within a specific period of time. Dessler (2011) defined it as an assessment of performance compared to previous or standard performance rates. For Elhouli \& Eddegni (2008), performance evaluation means obtaining specific facts or data, which help to analyse, understand and judge the worker's performance of his work, within a specific time period, and to assess his technical, practical and scientific competence to carry out the duties related to his current and future work. The official administrative definition, from the Ministry of Civil Service, is that performance evaluation is the measurement of an employee's performance according to the performance of the tasks assigned and following certain criteria. Performance is usually evaluated annually by the line manager.

- Organisational Performance or the Performance of Workers in Public Institutions

Organisational performance in the public sector, as well as in the health services, has been a subject of interest to researchers (e.g., Van der Heijden \& Mlandi, 2010; Ramseook-Munhurrun, Lukea-Bhiwajee, \& Naidoo, 2010; Minnaar, 2006) as well as to those responsible for the health sector, in order to achieve public spending effectiveness and provide good healthcare services. Organisational performance includes the organisation's actual outputs or outcomes as measured by targeted outcomes or by the goals and purposes in the organisation's strategic plan (Pycraft, 2007; Shortetal, 2016). Organisational or employee performance is affected by the nature and quality of each of the inputs, especially from human resources and the processes used in providing the service, as organisational performance can be seen as the result of a number of contributing factors that include operations and are linked to human competencies, organisational structures, senior management team, overall management style and HR management.

The organisational performance in the private sector differs from that in the public sector (Elbelbissi, 2012), as there is no profit motive in the public sector, and therefore the cash yield or income from providing the service is not contained in public institutions. This makes it difficult to use the traditional standards, apart from financial performance and known financial ratios, yet efficiency and cost-effectiveness considerations remain: institutions are accountable to the public, and to officials and guardians. Consequently, many studies have sought to establish standards away from traditional performance measures. Performance problems in public sector institutions are addressed from various pers- 
pectives, the most important of which is achieving effective and efficient provision of public goods and services (Putu et al., 2007). Mustapha (2006) and Zaghloul (2008) indicate that public sector performance in the core areas is governed by elements including strategic leadership, human resources, financial resources, infrastructure, programming, operations management and inter-institutional cooperation.

\section{- Measuring Organisational Performance in Public Institutions}

The process of measuring organisational performance is defined as the process of comparing business results with previously planned goals, to ensure efficiency of implementation, identifying the difficulties faced by the organisation in implementing what was previously planned, and deciding how to remove these obstacles or avoid them in the future. The process of measuring organisational performance in public institutions also aims at determining the efficiency and effectiveness of organisations in the performance of the tasks assigned to them, and can also be seen as the process of creating a work environment in which people are able to perform to their potential, ensuring goals are consistently, effectively and efficiently achieved (Al-Qahtani, 2012). Measuring organisational performance can include the performance of an organisation, department, employee, or even product or service rendering, as well as many other fields (Langley, 2007). Identification of specific criteria for measuring organisational performance in public institutions is considered difficult (Langley, 2007), as is the development of indicators to measure quality in a task. This is in line with the opinion of Kazan, Pekkanli, \& Catal (2012) who report that there is no general agreement on appropriate indicators.

\section{Methodology}

The research relied on a descriptive approach: a review of the theoretical framework and the concepts of the study to contribute to understanding; interpreting the relationship between variables; reviewing of the theoretical literature, and previous studies on the subject of this research, analysis of the results, and then the possibility of developing a theoretical model to study the effect of the quality of working life on the performance of workers and its application to Dawadami public hospital employees.

Based on the size of the study community (850), a stratified random sample consisting of 231 individuals was selected, which is the required size statistically with a confidence degree of $95 \%$ and a standard error coefficient (5\%), specified for the electronic tables prepared for this purpose. A Structural Equation Modeling (SEM) method was adopted, using the partial least squares method (PLS), V.2. PLS Smart Statistical Program was used to complete this purpose. Statistical methods based on Pearson correlation coefficient, Mann-Whitney test, the Croscal and Wallace test for some hypotheses of the study, and the SPSS $25 . \mathrm{V}$ statistical program have been relied upon in this study.

As shown in Table 1, the Dawadami public hospital employs 580 workers in 
various disciplines and categories, including a large number of non-Saudis, who comprise $96.6 \%$ of doctors and $46.3 \%$ of those in nursing services. There is a wide variety of nationalities among the non-Saudi workers, which brings differences in cultural and work values, and in factors which motivate and incentivise. The research community includes all 580 administrative and technical employees in the Dawadami Hospital. The research sample includes department managers, department heads, unit heads, supervisors and technical staff.

\section{Results}

A Structural Equation Modeling (SEM) method was adopted, using the partial least squares method (PLS) with the V.2 PLS Smart Statistical Programme used to complete this purpose. Statistical methods were also used: the Pearson correlation coefficient, the Mann-Whitney test, the Croscal and Wallace test for some hypotheses, and the SPSS 25.V statistical programme was relied upon to complete this purpose.

\subsection{Evaluation of the Study Tool}

The survey list was used to collect field data from the study sample, and the model was evaluated for reliability of respondents' answers by assessing the virtual validity of the survey, sincerity of convergence, internal consistency, stability of affiliation and preferential honesty with the aim of ensuring that the survey statements are appropriate to the model before performing the structural analysis and hypothesis testing, as detailed below:

- Virtual Validity

The survey list was presented in its preliminary form to a number of business experts for virtual validity testing and to ensure the adequacy of the survey statements and the accuracy of the expression of their intended terms. In light of the opinions of these experts, the wording of the survey was modified, with phrases that the arbitrators saw as weakly related to the study variables deleted. The list was then prepared and stated to verify construction sincerity and consistency.

- Convergence Validity

The convergence validity of the study model was evaluated by the loading values of each of the survey phrases (44 phrases), in addition to the AVE values for each dimension of the study. Table 2 shows the values of loading and average variance extracted for the survey list.

Table 1. Staff at Dawadami public hospital.

\begin{tabular}{cccc}
\hline Categories/Nationality & Saudi & Non-Saudi & Total \\
\hline Doctors & 4 & 112 & 116 \\
Nursing & 130 & 112 & 242 \\
Support treatment services & 144 & 13 & 157 \\
Administrators and users & 65 & - & 65 \\
Total & 343 & 237 & 580
\end{tabular}


Table 2. Loading values and average variance extracted for survey phrases.

\begin{tabular}{|c|c|c|c|c|c|c|c|c|}
\hline & \multicolumn{7}{|c|}{ Loadings } & AVE \\
\hline Phrases & (1) & (2) & (3) & (4) & (5) & (6) & & \\
\hline Wages and salaries & 0.801 & 0.789 & 0.785 & 0.759 & 0.670 & 0.749 & & 0.578 \\
\hline Phrases & (7) & (8) & (9) & (10) & (11) & & & \\
\hline Occupational safety and health & 0.739 & 0.777 & 0.772 & 0.667 & 0.757 & & & 0.553 \\
\hline Phrases & (12) & (13) & (14) & (15) & (16) & (17) & (18) & \\
\hline Job Satisfaction & 0.784 & 0.759 & 0.749 & 0.786 & 0.723 & 0.757 & 0.754 & 0.576 \\
\hline Phrases & (19) & (20) & (21) & (22) & (23) & & & \\
\hline $\begin{array}{l}\text { Opportunities for promotion } \\
\text { and career advancement }\end{array}$ & 0.744 & 0.824 & 0.805 & 0.765 & 0.701 & & & 0.591 \\
\hline Phrases & (24) & (25) & (26) & (27) & (28) & (29) & (30) & \\
\hline Dominant leadership style & 0.536 & 0.786 & 0.775 & 0.783 & 0.776 & 0.712 & 0.548 & 0.505 \\
\hline Phrases & (31) & (32) & (33) & (34) & (35) & (36) & (37) & \\
\hline Work environment & 0.741 & 0.852 & 0.827 & 0.840 & 0.111 & -0.0004 & -0.024 & 0.382 \\
\hline Phrases & (38) & (39) & (40) & (41) & (42) & (43) & $(44)$ & \\
\hline Staff performance & 0.722 & 0.772 & 0.834 & 0.725 & 0.814 & 0.807 & 0.790 & 0.611 \\
\hline
\end{tabular}

It is clear from these results that five phrases achieved loading values below the acceptable threshold in social research (0.6): phrases (24), (30), (35), (36) and (37), as the values of the average variance extracted for all dimensions of the study exceeded the minimum acceptable limit (0.5), with the exception of the dimension of work environment, due to the inadequacy of the loading of some explanatory expressions. These terms have therefore been deleted and the analysis was repeated to show an improvement in the loading values as well as in the values of the extracted average contrast variance. Hence, the survey was approved to suit the model, with the inclusion of 39 phrases only.

- Internal Consistency

To test the degree of internal consistency, the Alpha Cronbach coefficient was used to calculate the internal correlation between survey phrases and the study dimensions, taking into account that the minimum acceptable value of the $\alpha$-coefficient is 0.6 according to Hair et al. (2010). As shown in Table 2, all $\alpha$ values for the dimensions of the study exceeded 0.6 , which indicates the stability of the internal consistency of the phrases.

- Stability of Construct

The stability of construct test was performed for the 37 survey phrases. As can be seen from Table 3, the CR values for all dimensions of the survey exceeded the acceptable minimum level of 0.6 , which indicates a good level of stability for the study tool. 
Table 3. Results of the evaluation of the study model.

\begin{tabular}{cccccc}
\hline Study dimensions & $\alpha$ & CR & AVE & Sq. Root AVE & Correlation \\
\hline Wages and salaries & 0.852 & 0.891 & 0.578 & 0.760 & 0.747 \\
Occupational safety and health & 0.798 & 0.860 & 0.553 & 0.744 & 0.715 \\
Job Satisfaction & 0.877 & 0.905 & 0.577 & 0.760 & 0.703 \\
$\begin{array}{c}\text { Opportunities for promotion } \\
\text { and career advancement }\end{array}$ & 0.827 & 0.878 & 0.592 & 0.770 & 0.721 \\
$\quad \begin{array}{c}\text { Dominant leadership style } \\
\text { Work environment }\end{array}$ & 0.840 & 0.887 & 0.612 & 0.782 & 0.701 \\
$\quad$ Staff performance & 0.836 & 0.891 & 0.673 & 0.820 & 0.744 \\
\hline
\end{tabular}

- Preferential Validity

Preferential validity was tested to ensure that each study dimension fundamentally differs from the other dimensions. The Fornell-Larcker criterion was adopted by comparing the square root of the average contrast obtained with the highest correlation value between phrases and their own dimension. As can be seen from Table 2, the square root values of the average variance extracted for all dimensions exceeded the highest value in the Correlation Matrix between phrases and their dimension, which indicates a good level of preferential validity in the study tool.

\subsection{Evaluation of the Structural Model}

The constructive structural model of the study was evaluated to ensure its suitability for hypothesis testing through a set of criteria shown in Table 3 above, with Standardized Root Mean Square (SRMR), Normed Fit Index (NFI). The appropriateness of the constructive structural model of the analysis was established, where the value of SRMR $=0.043$, which is less than the acceptable maximum (0.08), and also the value of NFI $=0.91$, which is greater than the acceptable minimum (0.9), which, according to Hair et al. (2010), indicates acceptable quality in the constructive structural model of the study.

* Hypothesis Tests

- H1: There is no significant relationship between the dimensions of the quality of working life and the performance of workers at the Dawadami Hospital.

To test this hypothesis, Pearson correlation coefficient was adopted using SPSS V. 25, and the results are shown in Table 4.

It is clear from Table 4 that the first hypothesis, $\mathrm{H} 1$, is not correct, as the results of the statistical correlation analysis confirm the existence of a strong direct correlation relationship between all dimensions of quality of working life and the performance of the employees of the Dawadami hospital, a relationship of statistical significance at the level of significance (0.05) or less. The values of correlation coefficients show that the correlation between the dimensions of quality of working life and the performance of the employees is a strong and effective connection, where those values range between 0.685 and 0.766 , confirming a strong positive correlation between the two study variables. 
Table 4. Pearson correlation coefficients for the two study variables.

\begin{tabular}{ccc}
\hline Independent variable & Dependent variable & Staff performance \\
\hline Wages and salarie & Correlation coefficient & $0.700^{*}$ \\
Occupational safety and health & P-value & 0.000 \\
Cob Satisfaction & P-value & $0.692^{*}$ \\
Cpportunities for promotion and & Correlation coefficient & 0.000 \\
career advancement & P-value & $0.753^{*}$ \\
The dominant leadership style & P-value & 0.000 \\
& Correlation coefficient & $0.685^{*}$ \\
Work environment & P-value & 0.000 \\
& Correlation coefficient & $0.766^{*}$ \\
& P-value & 0.000 \\
\hline
\end{tabular}

- H2: Working life quality has no significant effect on the performance levels of employees of the Dawadami hospital.

To test this hypothesis, a constructive structural model for study variables was used through the Smart PLSV.2 program. Table 5 shows the results of the evaluation of the constructive structural model of the study, as well as that Figure 1.

- The QWL

Checks from the data of Table 5 show that all path parameter values for the independent variable dimensions (wages, salaries, occupational safety and health, job satisfaction, opportunities for promotion and career advancement, the prevailing leadership style and work environment) are statistically significant at a level of significance of (0.05) or less, which confirms that the second hypothesis of the study is incorrect, as it was found that there was amoral effect from the quality of working life on the job performance of workers in the Dawadami Hospital. Through the transaction values in the model, the relative importance of the impact can be seen for each dimension of the quality of working life in the performance of the workers, with the greatest influence from Dominant Leadership Style (standard path factor $=0.235$ ); in second place, Work Environment (standard path factor $=0.226$ ); in third place, Job Satisfaction(standard path factor $=0.159$ ), in fourth place, Salaries and Wages (standard path factor $=0.133)$, in fifth place, Opportunities for Promotion and career advancement (standard path factor $=0.111)$ and in sixth place, Occupational Health and Safety (standard path factor $=0.089$ ). As indicated by the value of the coefficient of determination (R), the combined dimensions of quality of life work explain $70.1 \%$ of the variance in workers' performance, while the error rate in the model $(29.9 \%)$ is due to other factors that are not mentioned in the model. 
Table 5. Evaluation of track transactions for the structural model of the study.

\begin{tabular}{cccccc}
\hline Tracks & Std. $\beta$ & Std. Dev. & T-value & P-value & F2 \\
\hline Wages and salaries & 0.133 & 0.067 & 1.972 & 0.031 & 0.12 \\
Occupational safety and health & 0.089 & 0.068 & 1.300 & 0.02 & 0.07 \\
Job Satisfaction & 0.159 & 0.088 & 1.805 & 0.04 & 0.14 \\
$\begin{array}{c}\text { Opportunities for promotion } \\
\text { and career advancement }\end{array}$ & 0.111 & 0.075 & 1.476 & 0.009 & 0.10 \\
$\begin{array}{c}\text { The dominant leadership style } \\
\text { Work environment }\end{array}$ & 0.235 & 0.077 & 3.033 & 0.001 & 0.21 \\
\hline
\end{tabular}

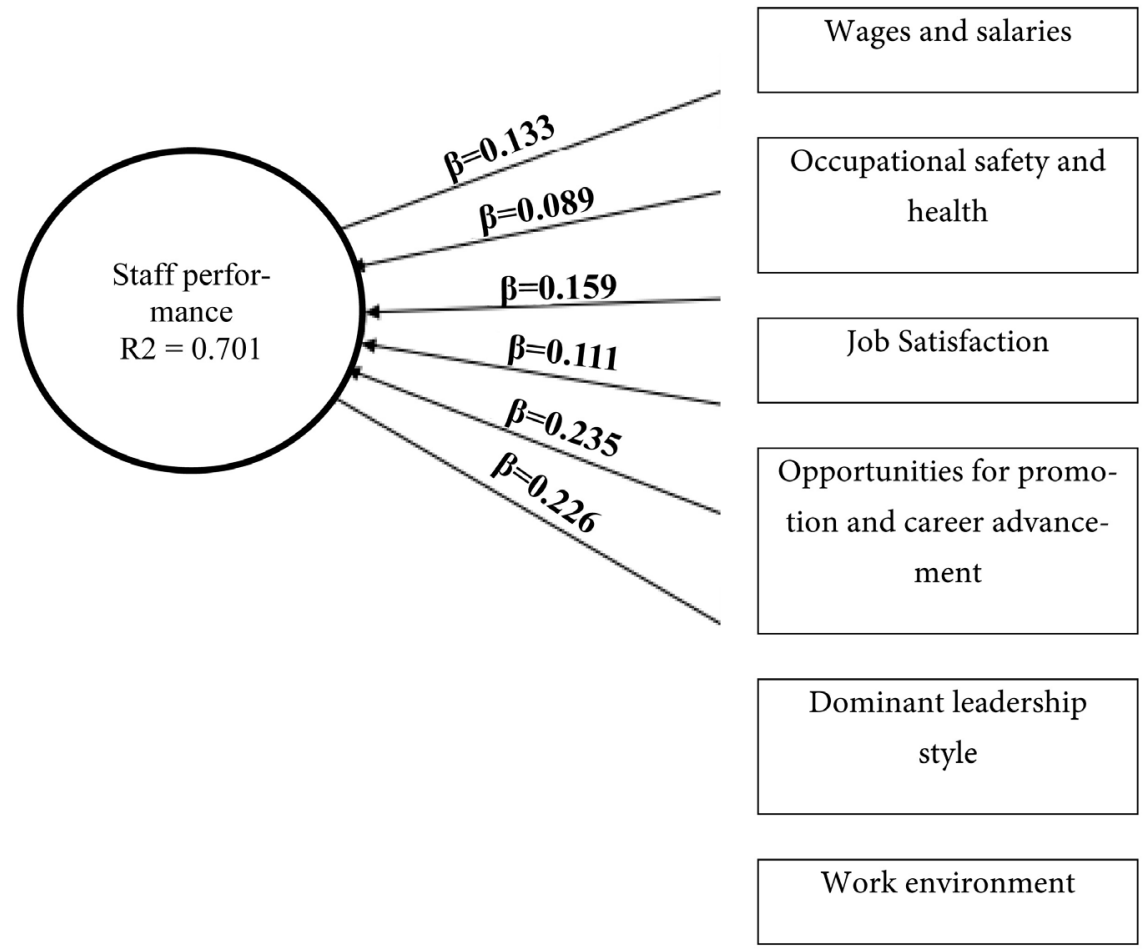

Figure 1. Analysis of the constructive structural model for study variables.

Table 5 shows the size of the impact (F) for each dimension of the quality of working life, where the values indicate that some QWL dimensions have a small influence on performance (Salaries and Wages, Occupational Health and Safety and Opportunities for Promotion and career advancement) and some have moderate effects (Job Satisfaction, Dominant Leadership Style and Work Environment). Finally, the predictive significance of the model was evaluated by Stone-Geisser's $\mathrm{Q} 2$ value. The value of $\mathrm{Q} 2=04136$, expresses a predictive accuracy of the combined dimensions of QWL in explaining the performance of workers, where the predictive importance of the model increases whenever the value of Q2 rises above zero.

- H3: There are no statistically significant differences between the averages of the respondents' responses regarding their opinions on the quality of work life, as its impact on the job performance of Al Dawadami Hospital em- 
ployees is due to personal and functional variables. To test this hypothesis, the Mann-Whitney and the Croscal and Wallace test non-patterned methods were used through the SPSS V.25 program, as shown in Table 6. The data in the previous table show the validity of the third hypothesis, as it was found that there were no significant moral differences in the opinions of the study sample items about any dimensions, whether according to type, age, educational level, type of job, number of years of service, or salary, as that is when morale level is 0.05 or less.

\section{Conclusion and Recommendations}

The research problem is to determine the most important elements of QWL affecting the job performance of workers at the Dawadami Hospital. The aims of the study are to identify the degree to which the dimensions of QWL are present, the relationship between the dimensions of QWL and the level of performance among workers at Dawadami hospital, and the difference in the level of employees' awareness of the dimensions of the QWL and its impact on job performance according to personal factors. The results of the study showed the answer to the main research question: what is the effect of QWL on the performance of workers at the Dawadami hospital?

The results were as follows:

- There is a strong direct correlation between all the dimensions of quality of working life (wages and salaries, occupational safety and health, job satisfaction, opportunities for promotions and career advancement, the prevailing leadership style and work environment) and the performance of Dawadami Hospital staff.

Table 6. Results of the third hypothesis test for the study.

\begin{tabular}{|c|c|c|c|c|c|c|c|c|}
\hline $\begin{array}{c}\text { Demographic } \\
\text { Variables }\end{array}$ & Statistics & $\begin{array}{l}\text { Salaries } \\
\text { and wages }\end{array}$ & $\begin{array}{c}\text { Occupational } \\
\text { health and safety }\end{array}$ & $\begin{array}{c}\text { Job } \\
\text { Satisfaction }\end{array}$ & $\begin{array}{c}\text { Opportunities for } \\
\text { promotion and career } \\
\text { advancement }\end{array}$ & $\begin{array}{c}\text { Dominant } \\
\text { leadership style }\end{array}$ & $\begin{array}{c}\text { Work } \\
\text { environment }\end{array}$ & $\begin{array}{c}\text { Staff } \\
\text { performance }\end{array}$ \\
\hline \multirow[t]{2}{*}{ Type } & $Z$-value & -0.132 & -0.801 & -0.580 & -0.149 & -0.256 & -0.204 & -0.136 \\
\hline & P-value & 0.895 & 0.423 & 0.562 & 0.881 & 0.791 & 0.839 & 0.892 \\
\hline \multirow[t]{2}{*}{ Age } & K.W.H. & 5.463 & 4.636 & 2.314 & 1.206 & 1.407 & 4.166 & 3.154 \\
\hline & P-value & 0.141 & 0.200 & 0.510 & 0.751 & 0.704 & 0.244 & 0.386 \\
\hline Educational & K.W.H. & 6.339 & 3.384 & 4.958 & 4.068 & 4.878 & 4.221 & 7.385 \\
\hline qualification & P-value & 0.175 & 0.496 & 0.292 & 0.397 & 0.300 & 0.377 & 0.117 \\
\hline \multirow[t]{2}{*}{ Job Type } & K.W.H. & 2.491 & 4.023 & 3.989 & 0.201 & 2.583 & 1.068 & 3.365 \\
\hline & P-value & 0.288 & 0.134 & 0.136 & 0.905 & 0.275 & 0.586 & 0.186 \\
\hline \multirow[t]{2}{*}{$\begin{array}{c}\text { Number of years' } \\
\text { service }\end{array}$} & K.W.H. & 3.061 & 1.615 & 0.651 & 0.320 & 0.016 & 1.022 & 1.545 \\
\hline & $\mathrm{P}$-value & 0.216 & 0.446 & 0.722 & 0.852 & 0.992 & 0.600 & 0.462 \\
\hline \multirow[t]{2}{*}{ Salary } & K.W.H. & 0.638 & 1.645 & 2.027 & 0.002 & 0.497 & 0.006 & 0.647 \\
\hline & $\mathrm{P}$-value & 0.425 & 0.200 & 0.155 & 0.962 & 0.481 & 0.937 & 0.421 \\
\hline
\end{tabular}


- It was found that there was a moral effect from the quality of working life on the job performance of workers in the Dawadami Hospital. The relative importance of the impact can be seen for each dimension of the quality of working life in the performance of the workers, with the greatest influence from Dominant Leadership Style (standard path factor $=0.235$ ); in second place, Work Environment (standard path factor $=0.226$ ); in third place, Job Satisfaction(standard path factor $=0.159$ ), in fourth place, Salaries and Wages (standard path factor $=0.133$ ), in fifth place, Opportunities for Promotion and career advancement (standard path factor $=0.111$ ) and in sixth place, Occupational Health and Safety (standard path factor $=0.089$ ).

- It was also found that all the dimensions of the quality of working life explain the variance in staff performance of $70.1 \%$ of the determination factor value of (R2).

- There are no significant moral differences in the opinions of the study sample items about any dimension, whether according to type, age, educational level, type of job, number of years of service or salary.

The study recommends that organisations focus on quality of working life due to its role in achieving a high level of performance in this institution, and specifically:

- Focusing on the dimensions of QWL represented in prevailing leadership style, work environment, job satisfaction, salaries and wages, opportunities for career advancement and promotions, and occupational health and safety.

- Institutions should work to achieve QWL.

- The need for institutions to develop a dominant leadership style that supports the application of QWL and move away from authoritarian and dictatorial patterns and from centralized practices, which limit workers' participation in decision-making.

- The need to deal with workers fairly, without discrimination and to use constructive criticism to improve performance and motivation to achieve institutional objectives.

- The need for institutional management to provide an environment in which employees feel secure in their jobs, which has a positive impact on improving staff performance.

- Giving attention to improving salary levels to suit the economic conditions, sufficient to satisfy personal needs and requirements.

- Raising the morale of employees and make them feel the important and positive role they play in achieving the goals of the institution by listening to their views and their suggestions, and encouraging them to develop their creativity, as well as maintaining dialogues and meetings with them.

\section{Conflicts of Interest}

The author declares no conflicts of interest regarding the publication of this paper. 


\section{References}

Abu-Sheikha, N. (2010). Human Resources Management-Theoretical Framework and Practical Cases. Amman: Dar Safaa for Publishing and Distribution.

Allagui, M. (2007). Human Resource Management. Saudi Arabia, Scientific Algorithm.

Al-Qahtani, M. (2012). Performance Measurement and Management in the Government Sector in Saudi Arabia.Second Conference. For the institutes of public administration and administrative development in the GCC countries.

Al-Thunaian, S. (2013). Exploring the Use of the Balanced Scorecard (Bsc). In the Healthcare Sector of the Kingdom of Saudi Arabia: Rhetoric and Reality. Unpublished PhD Thesis.

Bakar, A., Rozaini, R., \& Norailis, A. W. (2015). Roles of Organisational Support in Quality of Work Life in Insurance Industry. Journal of Economics, Business and Management, 3, 753-757. https://doi.org/10.7763/JOEBM.2015.V3.280

Battu, N., \& James, E. (2016). Quality of Work Life in Context: The Essential Impetus towards.

Bolhari, A., Rezaeean, A., Bolhari, J., Bairamzadeh, S., \& Soltan, A. (2011). The Relationship between Quality of Work Life and Demographic Characteristics of Information Technology Staffs. In International Conference on Computer Communication and Management Proc of CSIT, 5 (pp. 374-378). Singapore: IACSIT Press.

Carter, C., Pounder, F., Lawrence, F., \& Wozniak, P. (1989). Factors Related to Organizational Turnover Intentions of Louisiana Extension Service Agents, Presented at the Annual Conference on Quality-of-Life Studies in Marketing and Management (3rd, Blacksburg, VA, November 1989). In: H. Meadow, \& M. Sirgy (Eds.), Quality-of-Life Studies in Marketing and Management (pp. 170-181). Blacksburg, VA.

https://files.eric.ed.gov/fulltext/ED326943.pdf

Champoux, J. (1981). A Sociological Perspective on Work Involvement. International Review of Applied Psychology, 30, 65-86. https://doi.org/10.1111/j.1464-0597.1981.tb00980.x

Chanana, M., \& Gupta, S. K. (2016). Quality of Work Life and Its Impact on Job Performance: A Study of SBI \& HDFC Banking Professionals. International Research Journal of Management, IT \& Social Sciences, 3, 16-24.

https://doi.org/10.21744/irjmis.v3i5.12

Daud, N. (2010). Investigating the Relationship between Quality of Work Life and Organizational Commitment amongst Employees in Malaysian Firms. International Journal of Business \& Management, 5, 75-82. https://doi.org/10.5539/ijbm.v5n10p75

Davis, L., \& Cherns, A. (Eds.) (1975). The Quality of Working Life. New York: Free Press.

Dessler, G. (2011). Human Resource Management (13th ed.). New Jersey: Prentice Hall Publishing-Pearson Education, Inc.

Efraty, D., \& Sirgy, M. (1990). The Effects of Quality of Working Life (QWL) on Employee Behavioural Responses. Social Indicators Research, 22, 31-47. https://doi.org/10.1007/BF00286389

Efraty, D., Sirgy, M., \& Claiborne, C. B. (1991). The Effects of Personal Alienation on Organisational Identification: Quality-of-Work Life Model. Journal of Business and Psychology, 6, 57-78. https://doi.org/10.1007/BF01013685

Elbelbissi, O. (2012). Quality of Life and Its Impact on the Job Performance of NGO Workers in the Gaza Strip.

Elhosni, W. (2016). The Effect of Quality of Career on Enhancing Organisational Commitment of Social Researchers in the Ministry of Social Affairs.

Elhouli, A., \& Eddejni I. (2008). Experience of the Islamic University in Gaza in the Evaluation of Administrative Performance. 
Elomri, M., \& Randa, S. (2017). The Effect of Quality of Career on the Performance of the Public Employee: An Empirical Study on Civil Service Employees in Saudi Arabia. The Jordanian Journal of Business Administration, 13, 1-18.

Essouiti, S. (2016). About the Impact of the Quality of Work Life on Organisational Loyalty in the Palestinian Ministries. PhD Thesis, Khartoum: Sudan University of Science and Technology.

Greenhaus, J., Collins, K., \& Shaw, J. (2003). The Relation between Work-Family Balance and Quality of Life. Journal of Vocational Behavior, 63, 510-531. https://doi.org/10.1016/S0001-8791(02)00042-8

Hair, J. J., Black, W., Babin, B., \& Anderson, R. E. (2010). Multivariate Data Analysis (7th ed.). New Jersey: Pearson Prentice Hall.

Hamzah, A. R., Mu’taman, J., \& Omar, D. O. (2014). Leadership Styles and Performance of Public Sector Organizations: The Case of Saudi Arabia. Journal of Business Management and Accounting, 5, 55-62.

Hartmann, F., \& Slapnicar, S. (2009). How Formal Performance Evaluation Affects Trust between Superior and Subordinate Managers. Accounting, Organisations and Society, 34, 722-737. https://doi.org/10.1016/j.aos.2008.11.004

Indumathy, R., \& Kamalarj, S. (2012). Labor: A Study on Quality of Work Life among Workers with Special Preference to Textile Industry in Tirupur District a Textile Hub. International Journal of Multidisciplinary Research, 2, 265-281.

Jagatheesh, C. (2013). Quality of Work Life in the Industrial Estates of Kerala. Kerala: Mahatma Gandhi University.

Karimi, O., Daraei, M., \& Farajzadeh, F. (2015). Analyzing the Impact of Emotional Intelligence EI on the employees' Quality of Work Life QWL Case Study Central bureaus of Agricultural Bank in Tehran. Journal UMP Social Sciences and Technology Management, 3, 217-229.

Kazan, H., \& Gümüş, S. (2013). Measurement of Employees Performance: A State Bank Application. International Review of Management and Business Research (Peshawar), 2, 429-441.

Kazan, H., Pekkanli, B., \& Çatal, H.V. (2012). Performance Evaluation in Research and Development, Intellectual Capital, and Firm Infrastructure Projects as Intangible Assets. African Journal of Business Management, 6, 1872-1882.

Khera, A. (2015). Impact of Quality of Work Life on Job Satisfaction: An Empirical Study on Nurses of Government Hospital in Chandigarh (India). The International Journal of Business \& Management, 3, 34-45.

Langley, F. A., \& Mackintosh S. F. (2007). Functional Balance Assessment of Older Community Dwelling Adults: A Systematic Review of the Literature. The Internet Journal of Allied Health Sciences and Practice, 5, 1-11.

Lawler, E. (1982). Strategies for Improving the Quality of Work Life. American Psychologist, 37, 66-37. https://doi.org/10.1037/0003-066X.37.5.486

Levering, R. (1988). A Great Place to Work. New York: Avon Books.

Maghaminejad, F., \& Adib-Hajbaghery, M. (2016). Faculty Members Quality of Work Life in Medical Education in Kashan University of Medical Sciences in 2012. Nursing and Midwifery Studies, 5, 1-4. https://doi.org/10.17795/nmsjournal35921

Mahmoud, M. A. (2015). Quality of career life and its relationship with administrative creativity of officials of promotional activities in Egyptian universities (unpublished doctoral thesis). Assiut University, Egypt.

Manhas, C. (2013). Relating Emotional Intelligence, Quality of Work Life and Job Satisfaction: A Study among Corporate Employees. Review of HRM, 2, 107-120. 
Mills, T. (1978). Quality of Work Life: What's in a Name. Detroit, MI: General Motors Corporation.

Minnaar, F. (2006). Integrated Performance Management: The Evolving South African Management Model. Journal of Public Administration, 41, 177-190.

Mustapha, A. (2006). Measuring and Managing Government Performance in Saudi Arabia. Dublin: Institute of Public Administration.

Nadler, D., \& Lawler, E. (1983), Quality of Work Life: Perspectives and Directions. Organizational Dynamics, 11, 20-30. https://doi.org/10.1016/0090-2616(83)90003-7

Nanjundeswaraswamy, T. S., \& Swamy, D. R. (2015). An Empirical Research on the Relationship. Bangladesh E-Journal of Sociological, 12, 41-52.

Nyaoga, R. B., Nyamwange, O., Onger, R. N., \& Ombati, T. O. (2010). Quality Management Practices in Kenyan Educational Institutions: The case of the University of Nairobi. African Journal of Business \& Management, 1, 14-28.

Orpen, C. (1981). The Conceptualization of Quality of Working Life. Perspectives in Industrial Psychology, 7, 36-69. https://doi.org/10.4102/sajip.v0i0.328

Pratama, M. D. (2015). The Related Applying Context Analysis of Quality of Work Life to Company's Employee Satisfaction Based on Lion Superindo Indonesia Company's Employee District Singosari of Malang City in the Context of Fenomonologist. Jurnal Ilmiah Mahasiswa FEB, 4, 1-10.

Putu, N., Mimba, S., Van-Heden, J., \& Tillema, S. (2007). Public Sector Performance Measurement in Developing Countries: A Literature Review and Research Agenda. Journal of Accounting and Organisational Change, 3, 16-17. https://doi.org/10.1108/18325910710820265

Pycraft, M. (2007). Operations Management. South Africa: Pearson Education.

Quinn, R., \& Shephard, I. (1974). The 1972-1973 Quality of Employment Survey. Ann Arbor, MI: Institute for Social Research, University of Michigan.

Ramseook-Munhurrun, P., Lukea-Bhiwajee, S., \& Naidoo, P. (2010). Service Quality in the Public Service. International Journal of Management and Marketing Research, 3, 37-50.

Rani, A. M. (2016). Quality of Work Life and Organizational Commitment Effect on Employees Performance (Case Study in Pt Binatama Akrindo). Performa, 13.

Rubel, M., \& Kee, D. (2014). Quality of Work Life and Employee Performance: Antecedent and Outcome of Job Satisfaction in Partial Least Square (PLS). World Applied Sciences Journal, 31, 456-467.

Saleem, I., \& Khurshid, A. (2014). Do Human Resource Practices Affect Employee Performance? Pakistan Business Review, 15, 669-688.

https://ssrn.com/abstract $=2381570$

Short, J. C., McKenny, A. F., Ketchen, D. J., Snow, C. C., \& Hult, T. G. M. (2016). An Empirical Examination of Firm, Industry, and Temporal Effects on Corporate Social Performance. Business \& Society Journal, 55, 1122-1156. https://doi.org/10.1177/0007650315574848

Sinha, C. (2012). Factors Affecting Quality of Work Life: Empirical Evidence from Indian Organisations. Australian Journal of Business and Management Research, 1, 31-40

Sirgy, M., Efraty, D., Siegel, P., \& Lee, D. (2001). A New Measure of Quality of Work Life (QWL) Based on Need Satisfaction and Spillover Theories. Social Indicators Research, 55, 241-302. https://doi.org/10.1023/A:1010986923468

Staines, G. (1980). Spillover versus Compensation: A Review of the Literature on the Relationship between Work and Non-Work, Human Relations, 33, 111-129. https://doi.org/10.1177/001872678003300203 
Stein, B. A. (1983). Quality of Work Life in Action: Managing for Effectiveness. AMA Membership Publications Division, New York: American Management Associations.

Stephen, A., \& Dhanpal, D. (2012). Quality of Work Life and Its Impact on Job Satisfaction in Small Scale Industrial Units: Employees Perspectives. SDMIMD Journal of Management, 3, 11-23.

Swamy, D. (2013). Quality of Work Life of Employees in Private Technical Institutions. International Journal for Quality Research, 7, 3-14.

Van Der Heijden, T., \& Mlandi, M. (2010). Organisational Success and Failure in the Public Sector. Journal of Public Administration, 6, 20-22.

Walton, R. (1974). QWL Indicators-Prospects and Problems. Studies in Personnel Psychology, 6, 7-18.

Walton, R. E. (1973). Quality of Work Life: What Is It? Sloan Management Review, 15, 11-21.

Werther, W., \& Davis, K. (2002). Human Resources and Personnel Management. New York: McGraw-Hill Series in Management.

Yousef, D. (1997). Satisfaction with Job Security as a Predictor of Organisational Commitment and Job Performance in a Multicultural Environment. International Journal of Manpower, 19, 184-200. https://doi.org/10.1108/01437729810216694

Zaghloul, J. (2008). A Proposed Model for Developing Multi-Criteria Strategic Performance Measurement Systems Using a Grading Analysis Methodology. Journal of Commerce for Scientific Research, Alexandria University, 45, No. 1. 